\title{
Light and Dark Symbols in Heart of Darkness
}

\author{
Caie Qu (Corresponding author) \\ School of Foreign Languages, Yan'an University \\ Shaanxi, Yan'an 716000, China \\ E-mail: qucaie@yahoo.com.cn \\ Xiaoxi Li \\ School of Foreign Languages, Yan'an University \\ Shaanxi, Yan'an 716000, China \\ E-mail: lixiaoxi@yahoo.com.cn
}

\begin{abstract}
In Heart of Darkness, Joseph Conrad employs a lot of symbols to develop this short novel. This paper focuses on symbols of light and darkness and their symbolic meanings to reveal how the author overthrows people's common understanding of those symbols.
\end{abstract}

Keywords: Joseph Conrad, Heart of Darkness, Symbol, Light, Darkness

Heart of Darkness is a novella written by Joseph Conrad. He utilizes several important literary techniques throughout the story. One predominant method of his storytelling is his use of light and dark symbolism. Generally, throughout the story, the narrator, Marlow, describes Europe and Europeans in terms of light and white, equating them with knowledge and civility, but he defines Africa and Africans in terms of darkness and blackness, equating them with mystery and savagery. However, as he proceeds deeper into the Inner Station, those light and darkness symbols are infused with special meanings which are contradictory to what they usually mean to readers. This paper, through analyzing the light symbols, the "Whited Sepulchre", and two darkness symbols, the African jungle and fog, endeavors to reveal how the author overthrows people's common understanding of those symbols.

A sepulcher implies death and confinement. The phrase "Whited Sepulchre" comes from the biblical Book of Matthew, "For you are like whitewashed tombs, which on the outside look beautiful, but inside they are full of the bones of the dead and of all kinds of filth. So you also on the outside look righteous to others, but inside you are full of hypocrisy and lawlessness."(Matthew 23:27-28). In the passage, Matthew describes "Whited Sepulchre" as something beautiful on the outside but containing horrors inside. In "Heart of Darkness", the "Whited sepulchre" is probably Brussels where the company's headquarters are located. The company labels its mission as one of civilizing and enlightening the native peoples, while, in reality, the work along the Congo River is profit-driven. The company's methods are savage and dehumanizing, resulting in decay and death to both white men and their colonial subjects. The map that Marlow sees in the company offices shows the continent overlaid with "blotches of color, a lot of blue, a little green, smears of orange, a purple patch, to show where the jolly pioneers of progress drink the jolly lager-beer. However, I wasn't going into any of these," continues Marlow, "I was going into the yellow. Dead in the centre. And the river was there-fascinating-deadly-like a snake"(Conrad, 1999, p.38). Although the map with different colors representing various imperial presences in Africa is a neutral object, Marlow's comments about the map reveal that imperial powers were not all the same. The yellow, dead in the centre covers the site of some of the most disturbing atrocities committed in the name of empire-building. Referring to the river as a snake brings to mind Satan and evil. The Congo River, then, is seen by Marlow as the center of evil.

The strongest colonial power in the Congo was that of Belgian. Historically However, Belgians had the reputation of being far and away the most cruel and rapacious of the colonial powers. In the novella the Belgian monarch speaks rhetorically about the civilizing benefits of colonialism, an idea which has been espoused by Marlow's aunt. Marlow obtains a job with the Belgian company that trades on the Congo River through the influence of his aunt who has friends in the company's administration. With all formalities completed, Marlow stops off to say goodbye to his aunt, who expresses her hope that he will aid in the civilizing of savages during his service to the company. She talks about "weaning those ignorant millions from their horrid ways" (Conrad, 1999, p.40). Marlow feels quite uncomfortable because he is well aware that the company operates for profit and not for the good of humanity. 
Similarly, the heads of the company justify what they are doing up the Congo River as being a mission of civilization. In fact, the Belgian presence there was marked by blood-shed inhumanity. It is obvious, as Held has stated, that imperialism has acquired a new form as formal empires have been replaced by new mechanisms of multilateral control and surveillance" (Held et al, 2002, p.5). So underneath the veneer of a noble mission associated with the color of pure light, there is the blackness of decay and corruption. As Marlow travels from the Outer Station to the Central Station and finally up the river to the Inner Station, he encounters examples of torture, cruelty, and near-slavery. He sees piles of decaying machinery and a group of black prisoners walking along in chains under the guard of another black man. He remarks, "I've seen the devil of violence, and the devil of greed, and the devil of hot desire; but by all the stars! There were strong, lusty, red-eyed devils, that swayed and drove men - men, I tell you. But as I stood on this hillside, I foresaw that in the blinding sunshine of that land I would become acquainted with a flabby, pretending, weak-eyed devil of a rapacious and pitiless folly" (Conrad, 1999, p.44). These devils symbolize the evils of imperialism in Marlow's opinion. At the Central Station, Marlow sees a native be bitterly beaten because of his supposed crime of causing a fire. "Serve him right. Transgression-punishment-bang! Pitiless, pitiless. That's the only way' said the indefatigable man with the moustaches" (Conrad, 1999, p.53). Conrad emphasizes the colonist's ill-treatment of native Africans as a part of the benevolent project of "civilization".

The narrative of the novella builds toward the Marlow's meeting with Kurtz, who is described as "a universal genius" (Conrad, 1999, p.55), a most important first-class agent who is reputed to be a great humanitarian, and who embodies the ideals and fine sentiments with which Europeans justify imperialism. As Watt states "Kurtz was presumably representing colonialism as enlightenment through the two values with which the symbol of a lighted torch is conventionally associated - education and hope for the future" (Watt, 1980, p.229). However, Kurtz has become ruthless and rapacious. Marlow says of him, "He begins with. his argument that 'we whites, from the point of development we had arrived at, must necessarily appear to them [savages] in the nature of supernatural beings - we approach them with the might as of a deity." (Conrad, 1999, p.78). But Kurtz's supposed desire to "civilize" the natives is strikingly contradicted by his postscript, "Exterminate all the Brutes" (Conrad, 1999, p.78).

In contrast to the white symbols, the African jungle is one of the symbols for darkness. To white Europeans, the grove is a symbol for primitiveness and savagery. And most readers connect the jungle with darkness. "The Jungle is the opposite of a moral symbol - it stands for the savage in man, for his utter isolation and his moral collapse" (Gillon, 1982, p.24). However, as Marlow proceeds deeper into the heart of the African jungle, he realizes that savagery is a primitive form of civilization. "What thrilled you was just the thought of their humanity - like yours - the thought of your remote kinship with this wild and passionate uproar." (Conrad, 1999, p.64).

With his first step into the grove at the Outer Station, Marlow has a feeling that he has stepped into "the gloomy circle of some Inferno"; "rushing noises filled the mournful stillness of the grove." (Conrad, 1999, p.44). Marlow's horror at the grove suggests that the true evils of this colonial enterprise are dehumanization and death. "Black shapes crouched, lay, sat between the trees, leaning against the trunks, clinging to the earth, half coming out, half effaced within the dim light, I all the attitudes of pain, abandonment, and despair" (Conrad, 1999, p.44). These natives are not enemies or madly insane as the whites in the station described, but they are sick, starving, dying, helpless and weak. In sharp contrast to these starved, deprived, wretched, shabby natives, the company's chief accountant is luxuriously dressed. "I saw a high starched collar, white cuffs, a light alpaca jacket, snowy trousers, clear necktie, and vanished boots" (Conrad, 1999, p.45). He teaches one of the native women to take care of his linen, though she dislikes the work. In effect, he has made a slave of the woman, which indicates the hypocrisy of the imperialism and the inhumane and brutal treatment of the natives by the whites.

Furthermore, through his contact with Kurtz, Marlow realizes what evil lies in the heart of human nature. When Marlow first learns of Kurtz's activities in the jungle, he attributes Kurtz's moral downfall or madness to his lack of connectedness with civilization. Marlow blames the dark, mysterious force of the jungle for Kurtz's actions.

At this point in the narrative, Marlow regards savagery as a vice having absconded with nature. "Never, never before, did this land, this river, this jungle, the very arch of this blazing sky, appear to me so hopeless and so dark, so impenetrable to human thought, so pitiless to human weakness" (Conrad, 1999, p.83). Finally, he becomes aware that the African jungle is not to be blame for the making of brutal and mad Kurtz, but "all Europe contributed to the making of Kurtz" (Conrad, 1999, p.77). Kurtz's engagement with his fiancé has been disapproved by her people for he is not rich enough. His colleagues, envying his talents, conspire against him. The unfair treatment in the civilized world fuels the evil hidden in his heart which overwhelms him once he gets away from the constraints of civilization.

Gradually, Marlow comes to understand that Kurtz's madness and brutality is a reflection of the evil that resides in the hearts of all men. The temptation of the grove, the dark side of human nature, has so strong a power over Kurtz that he would rather stay in primitive and savage Africa, free from virtual and legal boundaries of civilization than to return to civilization. Marlow says of Kurtz, "For the wilderness had patted him on the head, and behold, it was like a ball- an ivory ball; it had caressed him, and -lo!-he had withered; it had taken him, loved him, embraced him, got into his veins, 
consumed his flesh, and sealed his soul to its own by the inconceivable ceremonies of some devilish initiation" (Conrad, 1999, p.76). To Marlow, Kurtz is his inner id. On his way to Kurtz's station, he finds himself " lumped along with Kurtz as a partisan of methods for which the time was not ripe: I was unsound!" (Conrad, 1999, p.90). To some extent, Marlow's persistence in seeking Kurtz despite all hardships indicates that the real human nature displayed by Kurtz is very tempting to him. Even Kurtz's brutal actions are not shocking to Marlow. He remarks "I seemed at one bound to have been transported into some lightless region of subtle horrors, where pure, uncomplicated savagery was a positive relief, being something that had a right to exist-Obviously in the sunshine." (Conrad, 1999, p.86). He slowly realizes that he has something in common with Kurtz.

Fog, as it is described in the novella, is another symbol of darkness. It suggests not only obscurity but also distortion: it gives one just enough information to begin with a decision but no way to judge the accuracy of that information, which often ends up being wrong. "When the sun rose there was a white fog, very warm and clammy, and more blinding than the night- a cry, a very loud cry, as of infinite desolation, soared slowly in the opaque are...to me it seemed as though the mist itself had screamed, so suddenly, and apparently from all sides at once, did this tumultuous and mournful uproar arise" (Conrad, 1999, p.67). Literarily, the fog obscures Marlow's vision and leaves him with no idea of where he is going and knowing not whether open water lies ahead. He can only make a judgment based on voices and words which, however, seems to be from "all sides". He does not think the natives will attack, for their cries have sounded more sorrowful than warlike. All his judgments turn out to be wrong.

Metaphorically, this has been Marlow's situation for the most part of the story. He has had to formulate a notion of Kurtz based only on secondhand accounts of the man's exploits and personality. This has been both enriching and dangerous for Marlow. On the one hand, having the figure of Kurtz as an object for meditation has provided a distraction from his unpleasant surroundings. "It seemed to me I had never breathed an atmosphere so vile, and I turned mentally to Kurtz for relief- positively for relief. "I think Mr. Kurtz is a remarkable man', I said with emphasis" (Conrad, 1999, p.90). Kurtz gives Marlow a sense of possibility. At the same time, Marlow's fantasizing about Kurtz has its hazards. By becoming intrigued with Kurtz, Marlow becomes dangerously alienated from and disliked by the Company's representatives. "He started... turned his back on me. My hour of favor was over." (Conrad, 1999, p.90). "I offered him the report on the "Suppression of Savage Customs" with the postscriptum torn off. He took it up eagerly, but ended by sniffing at it with an air of contempt. "This is not what we had a right to expect', he remarked... He withdrew upon some threat of legal proceedings" (Conrad, 1999, p.100).

In short, through the experience of going deep into the Congo River, Marlow not only discovers the evil and brutality of imperialism but also finds the id, the evil side of human nature. The whites goes to Africa in the name of civilizing the savage people there. However, once they themselves break away from the constraints of civilization, they give in to the evil side of human nature. Kurtz's cannibalistic brutality exists in the sunshine. But what is more horrible is the intangible evil inside those civilized pilgrims. The "Whited sepulcher", Brussels, which represents the civilized world, is beautiful and splendid only on the outside, but inside it is full of hypocrisy and evil. The dark grove, on the one hand, suggests the primitiveness and savagery of Africans. On the other, it stands for a human nature whose corruption is shown clearly once it is unbound by the standards of white society. The fog symbolizes the ambiguity in which people who journey into the African jungle are plunged. Through these symbols, Conrad develops the themes of the story: the hypocrisy of imperialism, and the evil side of human nature which is brought out when men are less influenced by societal controls.

\section{References}

Conrad, Joseph. (1999). Heart of Darkness and Other Stories. Kent: Wordsworth Classics, pp. 36-108.

Gillon, Adam. (1982). Joseph Conrad. Boston: Twayne Publishers, p.24.

Held, David et al. (2002). Globalizatio/Antiglobalization. Cambridge: Polity Press, p. 5.

Holy Bible, the New Testament. (2000). Nanjing: National TSPM \& CCC, 2000, 46.

Watt, Ian. (1980). Conrad in the Nineteenth Century. London: Chatto \& Windus Ltd., p.229. 